\title{
黔桂喀斯特山区年 NDVI变化的影响因素研究
}

\author{
刘梁美子 ${ }^{1,2}$, 占车生 ${ }^{1^{*}}$, 胡 实 $^{1}$, 张 琦 ${ }^{1,2}$ \\ (1. 中国科学院地理科学与资源研究所陆地水循环及地表过程重点实验室, 北京 100101 ; \\ 2. 中国科学院大学, 北京 100049)
}

\begin{abstract}
摘 要: 喀斯特山区是中国典型的生态脆弱区, 区内的植被极易发生退化, 且退化后难以恢复。论文采用逐步多元 回归、相关性分析和残差分析等方法, 探讨了黔桂喀斯特山区气候变化特征及其NDVI变化的影响因素。结果表 明: 2002-2015 年研究区气候变化呈现暖湿化趋势, 但变化并不显著, 年降水量和年均温变化分别介于-15.6 25.6 $\mathrm{mm} / \mathrm{a}$ 和 $-0.08 \sim 0.06{ }^{\circ} \mathrm{C} / \mathrm{a}$ 之间, 年均增速分别为 $7.9 \mathrm{~mm} / \mathrm{a}$ 和 $0.00035^{\circ} \mathrm{C} / \mathrm{a}$ 。过去 $14 \mathrm{a}$ 内, 气候变化是影响 $\mathrm{NDVI}$ 变化 的关键因素 (贡献率约 95\%), 其中降水对植被 NDVI 的影响大于气温。残差分析表明, 近 14 a 来黔桂喀斯特山区 NDVI 残差和 NDVI 残差趋势的均值分别为 0.03 和 $0.0007 / \mathrm{a}$, 说明人类活动的正效应呈上升趋势。城市化的进程使 得大量耕地、林地被建设用地占用, 在毕节、安顺、贵阳以及河池、柳州、百色一带, 人类活动对植被 NDVI变化呈较 明显的负效应, 但是在六盘水、黔西南自治州、遵义和来宾, 由于一系列生态还林工程的实施, 人类活动则表现为正 向影响。
\end{abstract}

关 键 词: 植被变化; 气候因子; 人类活动; 喀斯特山区

植被变化受气候变化和人类活动共同影响 (Zhang et al, 2016)。已有研究从全球(Ichii et al, 2002; Liu et al, 2016)、区域(Yin et al, 2016; 杜加强 等, 2016; Herrmann et al, 2017)等尺度, 采用不同的 研究方法, 如相关性分析(童晓伟等, 2014)、因子分 析(孙艳玲等, 2007)、回归分析(张雪梅等, 2017)、 Granger 因果检验(Philippon et al, 2005), 分析了气 候因子对植被变化的影响。虽然影响植被变化的 气候因子具有区域差异, 但降水和气温是影响植被 生长最为显著的 2 个气候因子(马明国等, 2006)。 一般来说, 降水是植被生长的水分来源, 在干旱半 干旱区, 降水是植被生长的主要限制因子; 气温影 响植被光合作用和呼吸作用的速率, 并通过影响土 壤微生物的活性影响植物对养分的利用效率(王彦 颖, 2016), 在温带或寒温带地区, 是影响植被变化 的主要原因(侯美亭等, 2013)。除气候因子外, 人类
活动如城市建设、生态工程、森林砍伐等, 也影响植 被生长和覆盖情况(侯美亭等, 2013), 且随着人类活 动的不断加强, 其作用也越来越显著。由于人类活 动的影响难以定量化, 大多数有关人类活动的研究 均采用定性描述的方式(郭敏杰, 2014)。归一化植 被指数(NDVI)残差是观测到的 NDVI 和 NDVI-气 候回归关系得到的理想 NDVI 之间的差异, 这种差 异被认为是由气候之外的其他因素造成的(Archer, 2004; Evans et al, 2004), 是目前较为常用人类活动 研究的定量方法(李辉霞等, 2011; Liu et al, 2018)。

黔桂喀斯特山区生态环境脆弱, 由于人类的不 合理干扰，植被遭到破坏并发生退化。自 2000 年起 西南喀斯特地区实施了包括退耕还林工程、天然林 保护工程、石漠化专项治理工程在内的一系列生态 修复工程。近十几年来植被向着良性化的方向发 展, 且受地形因子影响, 高海拔植被恢复速率更快,

收稿日期:2019-01-07;修订日期:2019-04-25。

基金项目: 国家重点基础研究发展计划(973 计划)项目(2015CB452701); 国家自然科学基金项目(41571019,51779009)。[Foun-

dation: National Key Basic Research Program of China (973 Program), No. 2015CB452701; National Natural Science Foundation of China, No. 41571019 and 51779009. ]

第一作者简介: 刘梁美子(1995-), 女, 湖北黄冈人, 硕士生, 主要研究水文与水资源学。E-mail: liuliangmeizi17@mails.ucas.ac.cn *通信作者简介: 占车生(1975-), 男, 湖北黄冈人, 研究员, 主要从事流域水循环模拟研究。E-mail: zhancs@igsnrr.ac.cn 
低海拔缓坡处的植被生态建设需要进一步加强(刘 梁美子等, 2018), 然而植被恢复的原因仍未明确, 本文在之前研究工作的基础上, 进一步探寻喀斯特 山区植被变化的影响因素。近 $30 \mathrm{a}$, 西北、东北和 三大高原地区(包括青藏高原、内蒙古高原和黄土 高原) 是国内植被变化研究的热点区(杨雪梅等, 2016), 黔桂喀斯特山区作为典型的生态脆弱区, 多 以省或县为研究单元(童晓伟等, 2014; Tian et al, 2017), 鲜见以自然地貌划分的大尺度研究区。因 此, 本文以黔桂喀斯特山区作为研究对象, 运用逐 步回归方法寻找植被变化的主要气候因子, 分析了 降水和气温对植被变化的影响, 同时通过构建 ND$\mathrm{VI}-$ 气候模型, 运用残差法定量识别人类活动对植 被 NDVI变化的影响, 为未来黔桂喀斯特山区生态 工程的进一步实施提供科学依据。

\section{1 数据与方法}

\section{1 研究区概况}

黔桂喀斯特山区 $\left(22^{\circ} 05^{\prime} \sim 28^{\circ} 15^{\prime} \mathrm{N}, 104^{\circ} 15^{\prime} \sim\right.$ $110^{\circ} 25^{\prime} \mathrm{E}$ )研究范围的确定参考了中国国家自然地 图集中华南喀斯特地形图及亚洲喀斯特地形分布 图, 并在明确自然地理单元范围后, 套合中国县域分 布图界限, 涵盖自然地理单元面积超过县域面积 $50 \%$ 的县。该研究区位于中国西南地区, 东邻湖南、 西连云南、北接四川, 行政区划上包括贵州中南部和 广西中西部共计 107 个县, 总面积 25.28 万 $\mathrm{km}^{2}$ 。地
势自西北向东南逐渐降低,最高海拔为 $2800 \mathrm{~m}$ (图 1a)。区内共有 6 种土地利用类型(图 1b), 其占比表 现为: 林地 $(56.73 \%)>$ 耕地 $(25.67 \%)>$ 草地 $(14.77 \%)>$ 建设用地 $(1.84 \%)>$ 水域 $(0.97 \%)>$ 未利用地 (仅 $0.02 \%)$ 。气候类型属于亚热带季风性气候, 年平均 气温多高于 $15{ }^{\circ} \mathrm{C}$, 年降水充沛 $(>1200 \mathrm{~mm})$, 雨季明 显,受季风影响多集中在 4-10月。

\section{2 数据来源及处理}

本文使用研究数据主要包括遥感数据、气象数 据及地理数据。其中, NDVI数据采用 GIMMS NDVI 卫星遥感数据 (https://ecocast.arc.nasa.gov/data/ pub/gimms/), 空间分辨率 $8 \mathrm{~km}$, 时间分辨率 $15 \mathrm{~d}$, 采 用国际通用的最大值合成法(MVC) 将半月数据处 理为年数据。气象数据来自中国气象局气象数据 中心(http://data.cma.cn/), 包含喀斯特山区内 21 个 站点 1982-2015 年的大气压强、平均气温、相对湿 度、风速、降水以及日照时数的日数据, 其中, 大气 压强、平均气温、相对湿度、风速 4 项气象数据取均 值作为年值, 降水和日照时数取日累积量作为年总 量, 并利用ANUSPLIN 软件对篮选出的气候因子 (年均温和降水量)进行插值。地理数据主要包括数 字高程模型(DEM) 和土地利用的数据。DEM数据 通过中国科学院计算机网络信息中心国际科学与 技术数据镜像站点(http://www.gscloud.cn)获得, 空 间分辨率为 $90 \mathrm{~m}$ (图 1a)。2015 年的土地利用数据 (LUCC) 由中国科学院资源环境科学数据中心提供 (http://www.resdc.cn/Default.aspx), 包括 6 个一级
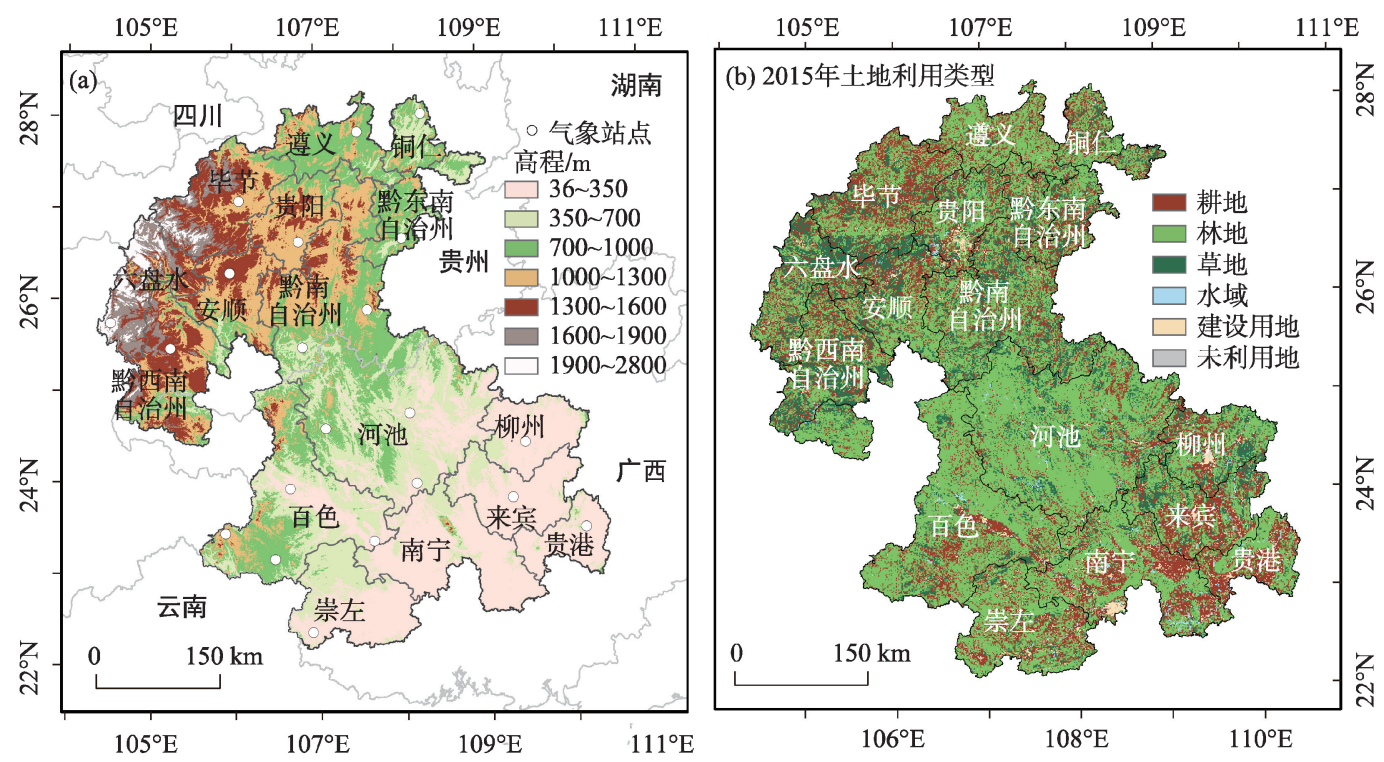

图 1 研究区高程及土地利用类型

Fig. 1 Elevation and land-use types of the study area 
类: 耕地、林地、草地、水域、城乡工矿及居民用地 (以下统称建设用地)和未利用地(研究区为裸岩), 数据空间分辨率为 $1 \mathrm{~km}($ 图 $1 \mathrm{~b})$ 。所有数据的统一 投影坐标为兰勃特方位等积投影。

\section{3 研究方法}

\subsection{1 逐步回归分析方法}

逐步回归方法指的是将变量逐个引人模型, 通 过显著性检验确定变量的引进和删除, 直到既没有 变量引人,也没有变量剔除为止。本文选用黔桂喀 斯特山区内 21 个气象站点的大气压强、平均气温、 相对湿度、风速、降水、日照时数 6 个变量, 经过数据 标准化后, 采用逐步回归分析方法对这些变量进行 篮选剔除。逐步回归的原理如下:

对 6 个回归自变量 $X_{1}, X_{2}, \cdots, X_{6}$, 分别同因变量 $Y$ 建立一元回归模型:

$$
Y=\beta_{0}+\beta_{i} X_{i}+\varepsilon \quad(i=1, \cdots, 6)
$$

计算变量 $X_{i}$ 相应的回归系数的 $F$ 检验统计量的 值, 记为 $F_{1}^{(1)}, \cdots, F_{6}^{(1)}$, 最大值记为 $F_{i 1}^{(1)}$, 即:

$$
F_{i 1}^{(1)}=\max \left\{F_{1}^{(1)}, \cdots, F_{6}^{(1)}\right\}
$$

显著性水平 $\alpha$ 下的临界值为 $F^{(1)}$, 若 $F_{i 1}^{(1)} \geqslant F^{(1)}$, 则将 $X_{i 1}$ 引人回归模型, 记 $I_{1}$ 为选人变量指标集合。

建立因变量 $Y$ 与自变量子集 $\left\{X_{i 1}, X_{1}\right\}, \cdots$, $\left\{X_{i 1}, X_{i 1-1}\right\},\left\{X_{i 1}, X_{i 1+1}\right\}, \cdots,\left\{X_{i 1}, X_{6}\right\}$ 的二元回归模型, 计算变量的回归系数 $F$ 检验的统计量值, 记为 $F_{k}^{(2)}$ $\left(k \notin I_{1}\right)$, 取最大值记为 $F_{i 2}^{(2)}$, 相应自变量脚标记为 $i_{2}$ 。

$$
F_{i 2}^{(2)}=\max \left\{F_{1}^{(2)}, \cdots, F_{i 1-1}^{(2)}, F_{i 1+1}^{(2)}, \cdots, F_{6}^{(2)}\right\}
$$

显著性水平 $\alpha$ 下的临界值为 $F^{(2)}$, 若 $F_{i 2}^{(1)} \geqslant F^{(2)}$, 则将 $X_{i 2}$ 引人回归模型。否则, 停止引人变量。考虑 因变量对变量子集 $\left\{X_{i 1}, X_{i 2}, X_{k}\right\}$ 的回归并重复以上 步骤, 直至无变量引人为止。

本文逐步回归过程中显著性水平 $\alpha=0.05$, 选出 对 NDVI 影响最大的气候因子, 最终篎选出的气候 因子为平均气温和降水, 采用这 2 项因子表征研究 区气候与植被 NDVI变化之间的关系。

\subsection{2 气象插值方法}

由澳大利亚学者 Hutchinson 开发的 ANUSPLIN 软件(Hutchinson et al, 2013)能同时进行多个表 面的空间插值,且该软件允许引人多个影响因子, 在复杂的山地条件下对气温、降水的插值精度较高 (于飞等, 2008; 谭剑波等, 2016), 在国际上得到了广 泛应用(刘志红等, 2008)。ANUSPLIN 软件基于普 通薄盘和局部薄盘样条函数插值理论。局部薄盘
光滑样条的理论统计模型表述如下：

$$
Z_{i}=f\left(x_{i}\right)+b^{\mathrm{T}} y_{i}+\varepsilon_{i} \quad(i=1, \cdots, N)
$$

式中: $Z_{i}$ 是位于空间 $i$ 点的因变量; $x_{i}$ 为 $d$ 维样条独立 变量, $f$ 为要估算的关于 $x_{i}$ 的未知光滑函数; $y_{i}$ 为 $p$ 维 独立协变量; $\varepsilon_{i}$ 为自变量随机误差。

式(4)中, 通过最小二乘估计确定函数 $f$ 和系数 $b^{\mathrm{T}}$, 具体如下:

$$
\sum_{i=1}^{N}\left[\frac{z_{i}-f\left(x_{i}\right)-b^{\mathrm{T}} y_{i}}{w_{i}}\right]^{2}+\rho J_{m}(f)
$$

式中: $J_{m}(f)$ 是函数 $f\left(x_{i}\right)$ 的粗䊁度测度函数, 定义为函 数 $f$ 的 $m$ 阶偏导(在ANUSPLIN 中称为样条次数, 也 叫粘度次数 $) ; \rho$ 是正的光滑参数, 在数据保真度与 曲面的粗䊁度之间起平衡作用, 通常由广义交叉验 证 GCV 的最小化来确定, 也可以用最大似然法 GML 或期望真实平方误差 MSE 最小化确定。

本文选用 ANUSPLIN 对 1982-2015 年喀斯特 山区的年平均气温和降水进行插值, 样条次数为 2 , 独立变量为经度和纬度,协变量为高程,气候因子 插值数据的空间分辨率为 $8 \mathrm{~km}$ 。

\subsection{3 相关性分析方法}

NDVI 的变化受多要素影响, 为了更好地分析 NDVI 与某变量的相关关系, 需要剔除其他变量的 影响, 因此采用基于像元的偏相关分析方法, 分别 计算年NDVI与降水、气温的偏相关系数,以探讨年 NDVI 与气候因子的关系。偏相关系数是基于简单 相关系数计算的, 简单相关系数的计算公式如下:

$$
r_{x y}=\frac{\sum_{i=1}^{n}\left(x_{i}-\bar{x}\right)\left(y_{i}-\bar{y}\right)}{\sqrt{\sum_{i=1}^{n}\left(x_{i}-\bar{x}\right)^{2} \sum_{i=1}^{n}\left(y_{i}-\bar{y}\right)^{2}}}
$$

式中: $r_{x y}$ 表示 $x 、 y$ 两变量的相关系数; $x_{i}$ 表示各年份 的 NDVI; $\bar{x}$ 表示多年年均 NDVI; $y_{i}$ 表示各年份的 年降水或年均气温; $\bar{y}$ 表示多年年均降水或气温; $i$ 表示样本数。

在计算简单相关系数的基础上计算偏相关系 数,其计算公式为:

$$
r_{x y z}=\frac{r_{x y}-r_{x z} r_{y z}}{\sqrt{\left(1-r_{x z}{ }^{2}\right)+\left(1-r_{y z}{ }^{2}\right)}}
$$

式中: $r_{x y} 、 r_{x z} 、 r_{y z}$ 分别表示变量 $x$ 和 $y$ 、变量 $x$ 和 $z$ 、变量 $y$ 和 $z$ 的简单相关系数(由简单相关系数计算公式求 得), $r_{x y z}$ 表示将变量 $z$ 的影响视作常量时, 变量 $x$ 和 $y$ 的偏相关系数。 $r_{x y z}>0$, 表示将变量 $z$ 的影响视作常 量时,变量 $x$ 和变量 $y$ 正相关,否则, 呈负相关, 且该 
值绝对值越大, 表明两变量相关性越强。此外, 采 用 $t$ 检验判断 NDVI 与降水、气温间偏相关系数的显 著性。统计量 $t$ 的计算公式如下:

$$
t=\frac{r_{x y z}}{\sqrt{1-r_{x y z}^{2}}} \sqrt{n-m-1}
$$

式中: $n$ 为样本数, $m$ 为自变量个数。

\subsection{4 残差分析法}

本文采用残差法分离气候因素和人为因素对 植被 NDVI 的影响。要建立NDVI-气候因子的理 想回归方程, 理论上应考虑植被完全不受人类活动 干扰的情况, 但这样的资料获取难度极大。由于黔 桂喀斯特山区大规模生态工程的实施在 2002 年以 后, 因此, 假设 2002 年以前研究区的植被系统、人类 活动、气候因子之间处于一种平衡状态(李辉霞等, 2011)。以 1982-2001年 $20 \mathrm{a}$ 的 NDVI和气候数据 逐像元建立 NDVI-气候模型, 针对每一个像元获得 单独的多元回归方程, 并对回归模型的结果进行 $F$ 检验。利用逐像元的多元回归方程模拟出 20022015 年研究区的 NDVI值, 并计算 NDVI 真实值与 预测值之间的残差, 认为这部分 NDVI 的差异是由 人为因素导致。

$$
\mathrm{NDVI}_{\text {预测值 }}(i, t)=a_{0}+a_{1} P(i, t)+a_{2} T(i, t)
$$

式中: $\mathrm{NDVI}_{\text {预测值 }}(i, t) 、 P(i, t) 、 T(i, t)$ 分别指的是第 $i$ 个像 元第 $t$ 年的 NDVI、降水和气温。 $a_{1}$ 和 $a_{2}$ 分别为降水 的回归系数, $a_{0}$ 为常数项。

$$
\varepsilon=\mathrm{NDVI}_{\text {真实值 }}-\mathrm{NDVI}_{\text {预则值 }}
$$

若 $\varepsilon$ 大于 0 , 表明人类活动产生正影响; 若 $\varepsilon$ 小于 0 , 表明人类活动产生负影响。

其中, 气候变化造成的影响用 NDVI 预测值来 衡量, 人类活动造成的影响用 NDVI 残差值来衡 量。气候变化和人类活动对 NDVI变化的贡献率计 算公式如下(孙建国等, 2012):

$$
C_{\text {eff }}=\frac{\mathrm{NDVI}_{\text {预测值 }}}{\mathrm{NDVI}_{\text {真实值 }}} \times 100 \%
$$

$$
H_{\text {eff }}=\frac{\varepsilon}{\mathrm{NDVI}_{\text {真实值 }}} \times 100 \%
$$

式中: $C_{\text {eff }}$ 表示气候变化对 NDVI变化的贡献率; $H_{\text {eff }}$ 表示人类活动对 NDVI变化的贡献率。

\section{2 结果与分析}

\section{1 影响 NDVI 的主要气候因子及其变化}

为探讨研究区内 NDVI 与气候因子之间的关 系, 首先采用逐步多元回归的方法, 以喀斯特山区 21 个站点(图 1)2002-2015 年的年 NDVI为因变量, 相应站点的 6 项气象数据(大气压强、平均气温、相 对湿度、风速、降水以及日照时数)为自变量, 对主 要的气候因子进行筷选(表 1)。选择回归效果更好 的模型 2 作为逐步多元回归的结果, 发现降水与气 温是影响 NDVI的主要气候因子 $(p<0.05)$, 回归方程 为 $\mathrm{NDVI}=-0.953 P+0.615 T+4.54 \times 10^{-11}\left(R^{2}=0.611, p<\right.$ $0.01)$ 。因此, 在以下研究中, 主要考虑降水和气温 对NDVI的影响。

时间尺度上(图 2), 2002-2015 年降水最高值为 $1664.13 \mathrm{~mm}$ (2015 年), 最低值为 $1004.9 \mathrm{~mm}$ (2011 年)。 年均温最高 $18.6{ }^{\circ} \mathrm{C}\left(2015\right.$ 年), 最低 $17.3{ }^{\circ} \mathrm{C}(2011$ 年)。 两者随时间均有上升的趋势, 但并不显著,降水的 变化较气温大, 前者的变化基本为先上升后下降再 上升, 后者则一直震荡变化, 表明研究区在 20022015 年间有逐渐暖湿的趋势。空间上(图 3), 黔桂 喀斯特山区 2002-2015 年年均降水为 $1349.5 \mathrm{~mm}$, 分布为南多北少。区域整体上降水增加 (约 $84.8 \%$ ), 平均增加趋势为 $7.9 \mathrm{~mm} / \mathrm{a}$ 。降水减少仅发 生在北部遵义、铜仁、毕节、六盘水的部分地区,最 大降水减少幅度达 $-15.6 \mathrm{~mm} / \mathrm{a}$; 南部多数地区降水 增加, 尤其是贵港、来宾等地, 最大降水增量至 25.6 $\mathrm{mm} / \mathrm{a}$ 。研究区 $2002-2015$ 年年均温为 $18.6{ }^{\circ} \mathrm{C}$, 自

\begin{tabular}{|c|c|c|c|c|c|}
\hline 模型 & 变量 & 系数大小 & 系数显著性水平 & $R^{2}$ & 标准估计的误差 \\
\hline \multirow[t]{2}{*}{1} & $P$ (降水) & -0.599 & $<0.01$ & 0.359 & 0.84 \\
\hline & 常数项 & $2.852 \times 10^{-11}$ & $<0.05$ & & \\
\hline \multirow[t]{3}{*}{2} & $P$ (降水) & -0.953 & $<0.01$ & 0.611 & 0.67 \\
\hline & $T$ (温度) & 0.615 & $<0.01$ & & \\
\hline & 常数项 & $4.54 \times 10^{-11}$ & $<0.05$ & & \\
\hline
\end{tabular}
西北向东南逐渐升高, 这是由于区内西北部海拔较 高, 气温相对较低,而地势低洼处则形成高值区(姚

表 1 气候因子逐步回归结果汇总

Tab.1 Results of stepwise regression about meteorological factors

注: 降水单位为 $\mathrm{mm}$, 温度单位为 ${ }^{\circ} \mathrm{C}$ 。 


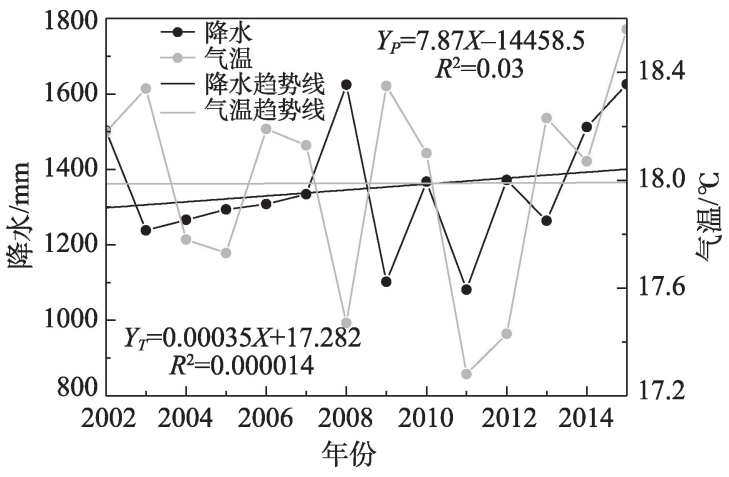

图 2 2002-2015 年喀斯特山区降水、温度变化

Fig.2 Trends of change of precipitation and temperature in karst mountain areas, 2002-2015
永慧, 2005); 近 $14 \mathrm{a}$ 研究区内整体略有增温(均值约 $\left.0.00035^{\circ} \mathrm{C} / \mathrm{a}\right), 53 \%$ 的区域气温有所升高, 主要发生 在研究区的西北和东南缘, 最高增温趋势为 $0.060{ }^{\circ} \mathrm{C} / \mathrm{a}$, 中部大部分和西北小部分地区气温存在 下降趋势(如河池、柳州), 其中河池的部分区域气温 降低趋势达 $-0.08{ }^{\circ} \mathrm{C} / \mathrm{a}$ 。

\subsection{NDVI 对气候变化的响应}

2002-2015 年年 NDVI与年降水、气温的偏相 关系数空间分布格局如图 4 所示。NDVI 与降水的 偏相关系数在 $-0.81 \sim 0.87$ 之间, 区域均值为 0.17 。 其中, 绝大部分 (约 72\%) 的区域显示 NDVI 与降水 呈正相关, $14.6 \%$ 通过了显著性检验 $(p<0.1)$, 显著正 相关的部分聚集在研究区东部。NDVI与降水负相
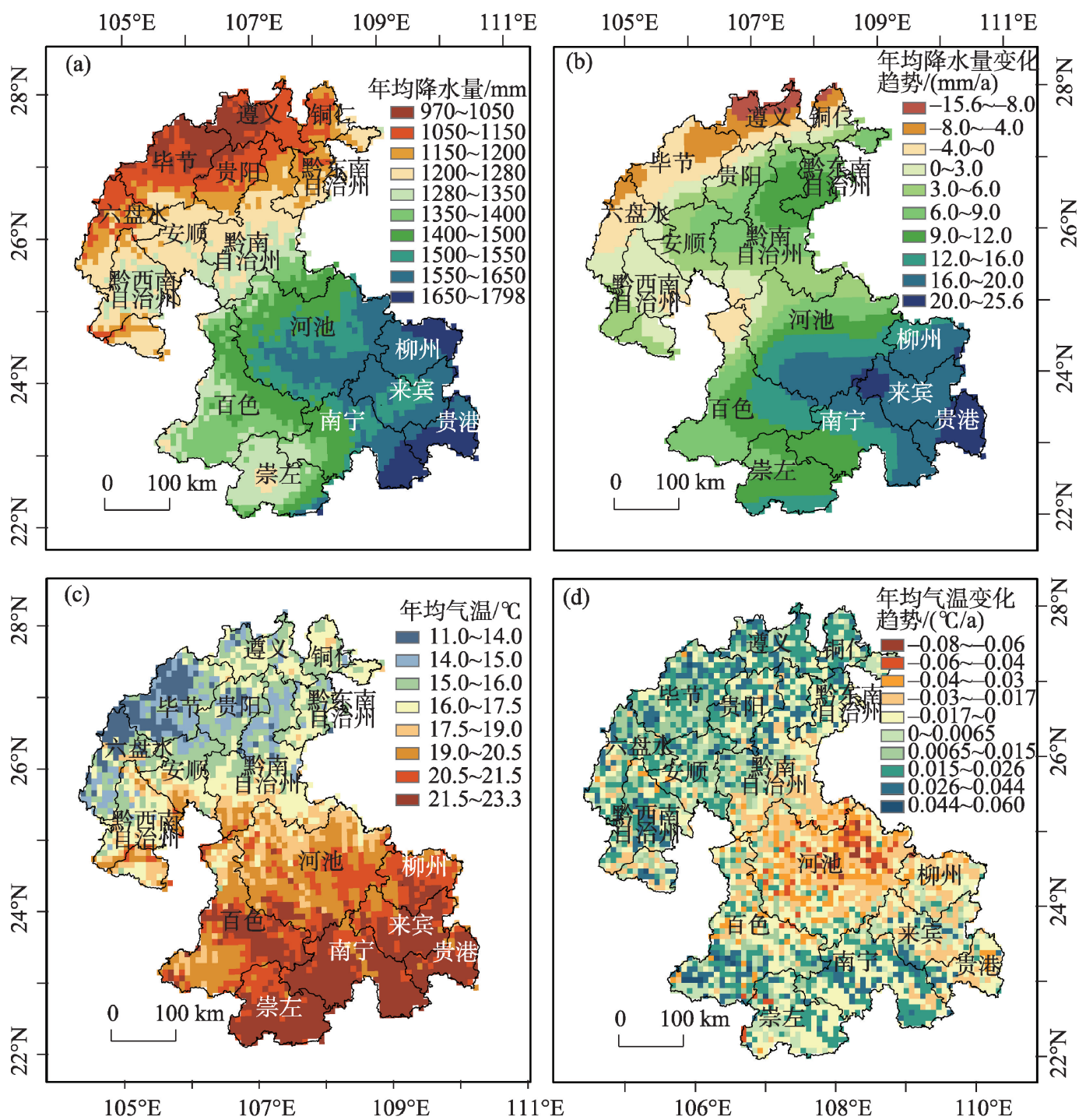

图 $32002-2015$ 年喀斯特山区年均降水、年均气温及其变化的空间格局

Fig.3 Spatial patterns of annual average precipitation, annual average temperature, and their changes in karst mountain areas, 2002-2015 
关的面积占比为 $28 \%$, 其中仅 $0.9 \%$ 通过了显著性检 验 $(p<0.1)$, 零星分布于区域内。NDVI 与气温的偏 相关系数范围为 $-0.71 \sim 0.75$ (均值 -0.01 )。具有正相 关关系的区域占 $46.7 \%$, 分布在研究区的北部和南 部,NDVI 与气温负相关的地区主要集中在中部(河 池和黔西南自治州)。

为进一步探究植被变化与降水、气温的关系, 对不同土地利用类型年 NDVI 与降水、气温的相关 性进行进一步的分析, 得到耕地、林地、草地 NDVI 与降水的偏相关系数分别为 $0.169 、 0.167 、 0.21$,与 气温的偏相关系数分别为 $0.02 、-0.02 、-0.007$ 。由 于降水增加能够促进植物根系的发育, 故不同土地 利用类型 NDVI 与降水的相关系数均大于 0 , 其中,
草本植物较木本植物对降水增加更为敏感, 与降水 的偏相关性较耕地和林地更大; 耕地与气温的相关 系数大于 0 ,林地和草地则小于 0 , 这是因为对耕地 而言, 温度升高有利于作物生长季延长, 对植被生 长有促进作用, 但对草本木本植物来说, 升温一方 面增加了土壤水分蒸发, 另一方面植物蒸腾作用加 强, 进而抑制植被生长。

\section{3 黔桂喀斯特山区 NDVI 与人类活动的关系}

本文利用黔桂喀斯特山区 1982-2001年 $20 \mathrm{a}$ 的 NDVI 和降水、气温数据建立了 NDVI-气候模 型, 得到的模型平均 $R^{2}$ 为 0.5 , 其中, $10.85 \%$ 的栅格 通过了显著性检验 $(p<0.1)$, 通过计算实际 NDVI 与 模拟 NDVI 的残差表示人类活动对植被年 NDVI变
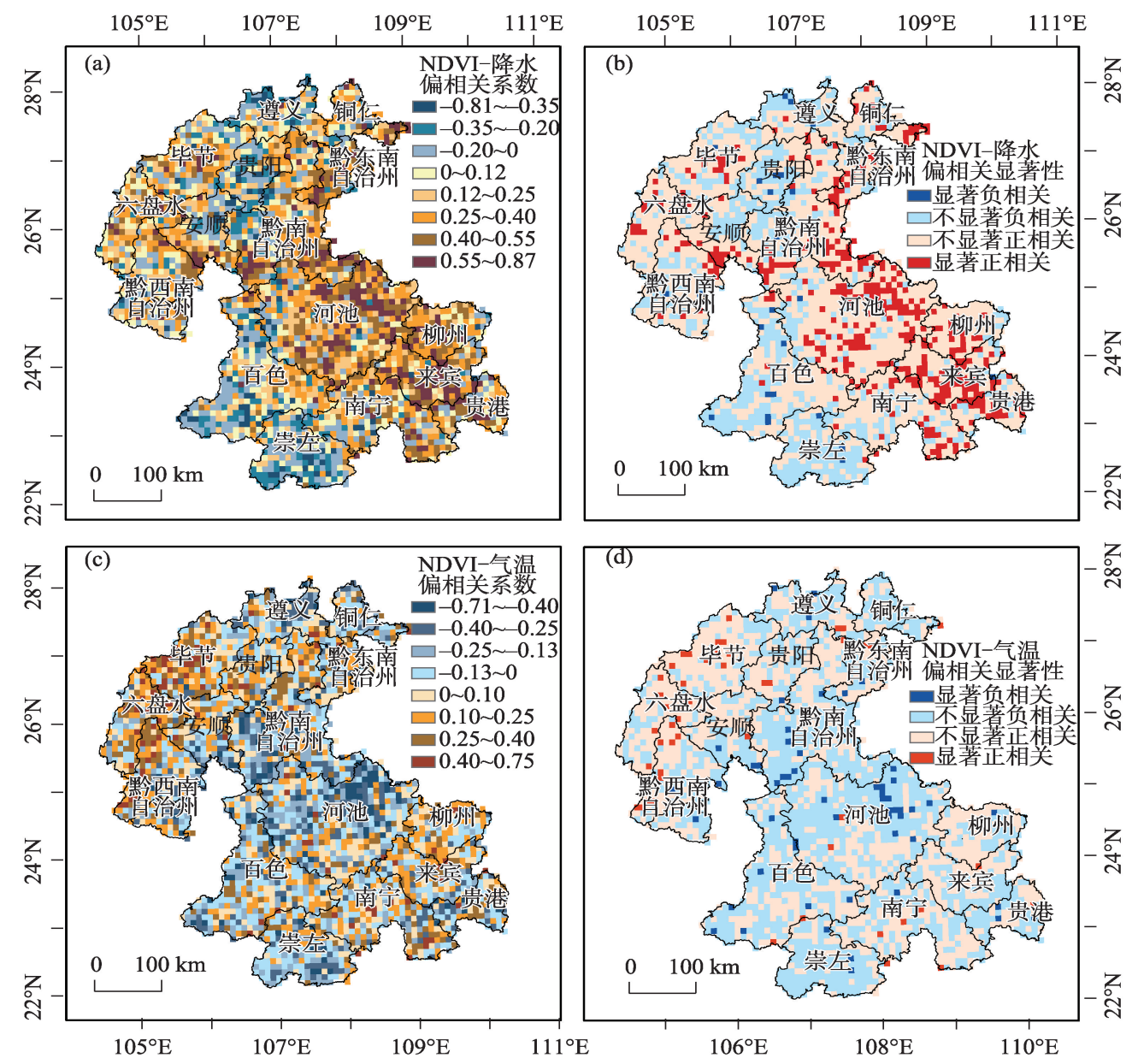

图 4 喀斯特山区 NDVI 与降水、温度的偏相关性及显著性 $(p<0.1)$

Fig.4 Partial correlation coefficients between NDVI and precipitation (a), temperature (c); and correlation significance between NDVI and precipitation (b), temperature (d) 
化的影响。研究结果表明, 近 $14 \mathrm{a}$ 来黔桂喀斯特山 区 NDVI 的平均残差为 0.03 , 说明人类活动对植被 变化整体呈现正向作用,一系列生态工程的实施已 见成效。从图 $5 \mathrm{a}$ 和图 $5 \mathrm{c}$ 可以看出, 在研究区西北和 东南一带, 人类活动对植被 NDVI 的影响和贡献最 为显著。人类活动呈负影响的区域集中在毕节、安 顺、贵阳以及河池、柳州、百色一带, 正影响的区域 主要分布于六盘水、黔西南自治州、遵义和来宾, 人 类活动对年 NDVI变化的影响远小于气候变化, 其 对 NDVI 的平均贡献率约为 $5 \%$, 气候变化的贡献率 则达 $95 \%$ 。从年 NDVI残差多年的变化趋势来看 (图 5b), 其变化范围介于 $-0.014 \sim 0.013 / \mathrm{a}$ 间, 均值为 $0.0007 / \mathrm{a}, 80 \%$ 以上区域的 NDVI 残差变化趋势为 正, 表明过去十几年间人类活动的正效应一直在显 现, 且有上升趋势, 除百色、崇左、南宁和柳州等区域 人类活动的负效应在加剧之外, 大部分区域人类活 动对植被NDVI的正影响在增加。

\section{3 讨论}

已有大量的研究表明, 气候因子是影响植被生 长及变化的重要因素(Hou et al, 2015; Wang et al, 2015)。黔桂喀斯特山区属亚热带季风性气候, 年 降水超过 $1200 \mathrm{~mm}$, 空气相对湿度偏大(大部分地区 大于 $70 \%$ ), 逐步多元回归的结果表明降水和气温是 喀斯特地区植被变化最重要的气候因子。

IPCC 第五次评估报告指出(IPCC, 2013), 在过 去的 130 多年间(1880-2012 年), 全球地表气温升
高 $0.85^{\circ} \mathrm{C}\left(0.65 \sim 1.06{ }^{\circ} \mathrm{C}\right)$, 各种生态系统均不同程度 地受到全球气候变化的影响。一般而言,气温和降 水是影响植被变化最主要的因素, 其中气温影响植 物光合作用和呼吸作用的速率以及对养分的利用 效率, 降水则主要影响植物生长的水分来源。近 $14 \mathrm{a}$ 来黔桂喀斯特山区呈暖湿化趋势, 虽然降水和 气温均没有显著的变化趋势, 但降水的变幅较气温 更为明显。降水、气温与 NDVI的偏相关系数分别 介于 $-0.81 \sim 0.87$ 和 $-0.71 \sim 0.75$ 之间, 由于研究区的 西北和东南缘的植被类型以农作物为主, 年均温适 当升高会导致植被生长季延长(蒙吉军等, 2007), 同 时促进植物的光合作用, 从而提高植被的 NDVI, 但 是气温升高的同时也增加了植物和土壤水的蒸散 发, 导致在林地广布的中部地区, 植被 NDVI 与气温 呈负相关关系。降水量增加能为植物生长提供更 充足的水分, 通常有助于植被的生长, 因此在黔桂 喀斯特山区, $72 \%$ 的区域 NDVI 与降水表现为正相 关关系。但阴雨天的增加也会导致太阳辐射减少, 使得植被的光合作用减弱, 故而在贵阳、百色、崇左 等部分区域存在NDVI减少的情况。

由于植被类型、研究区的区位及地形地貌、气 候因子本身的变化等原因,气候因素对植被变化的 影响存在极大的空间差异性(马明国等, 2006)。通 常, 在干旱半干旱地区和干湿季气候差异明显的地 区,降水是植被 NDVI变化的主导因素,而在温带或 寒温带地区,植被 NDVI对气温的响应更为显著(侯 美亭等, 2013)。2002-2015 年, 黔桂喀斯特山区 NDVI变化受降水的影响大于气温, 这可能与 $14 \mathrm{a}$
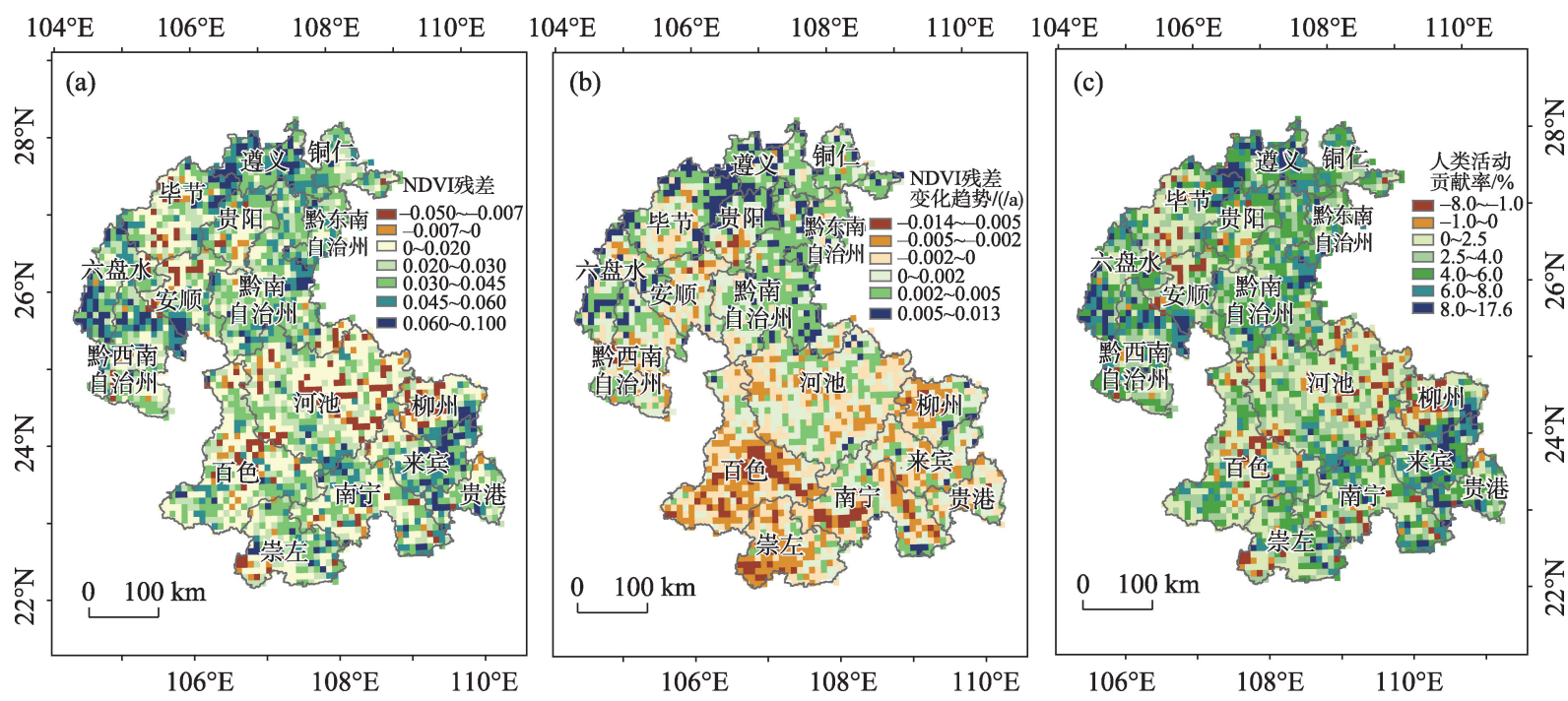

图 5 喀斯特山区的 NDVI残差(a)、残差变化趋势(b)及人类活动贡献率(c)

Fig.5 NDVI residual (a), change trend (b), and contribution rate of human activities (c) in karst mountain areas 
间降水和气温的变化及研究区自身气候特征, 如干 湿季分明有关, 降水平均增加 $7.9 \mathrm{~mm} / \mathrm{a}$, 而气温仅 上升了 $0.00035^{\circ} \mathrm{C} / \mathrm{a}$ 。除气候因子外, 人类活动也影 响着研究区内植被 NDVI 的变化 (李吴等, 2011; 童 晓伟等, 2014; Tong et al, 2017)。从残差法的结果 来看, 近十几年来黔桂喀斯特山区年 NDVI 的平均 残差为 0.03 , 说明人类活动对黔桂喀斯特山区植被 NDVI 呈现正效应,一系列生态工程和石漠化治理 工程的效益正在逐步体现, 且从 NDVI残差多年的 变化趋势来看, 其均值为 $0.0007 / \mathrm{a}, 80 \%$ 以上区域残 差趋势均大于 0 , 表明过去十几年间人类活动的正 效应一直在显现, 且有上升趋势。总体而言, 过去 $14 \mathrm{a}$, 气候变化是影响黔桂喀斯特山区 NDVI变化 的关键因素, 其平均贡献率高达 $95 \%$, 但人类活动 能在短时间尺度内加快植被变化的速度。贵州的 毕节、安顺、贵阳和广西的河池、柳州、百色一带, 耕 地和林地广布(图 1b), 近年来人口的快速聚集以及 城市化进程的加快, 大量耕地、林地被建设用地占 用,使得人类活动在这些地区呈较明显的负效应; 但是在六盘水、黔西南自治州、遵义和来宾, 人类活 动对植被 NDVI变化表现为正向影响,这也表明一 系列生态还林工程(自 2002 年开始大规模实施)对 喀斯特山区植被恢复的影响十分显著(Tong et al, 2017)。

\section{4 结论}

本文结合气候数据和遥感数据, 首先从站点尺 度运用逐步回归的方法篮选出影响黔桂喀斯特山 区NDVI 的主要气候因子, 随后采用相关分析及统 计方法从区域尺度研究NDVI变化与降水和气温的 关系; 此外采用残差法定量描述了人类活动对年 NDVI变化的影响, 探讨了研究区年NDVI变化的 影响因素, 主要结论如下:

(1) 2002-2015 年, 黔桂喀斯特山区年均降水量 为 $1349.5 \mathrm{~mm}$, 年均温为 $18.6{ }^{\circ} \mathrm{C}$, 由南至北, 降水逐 渐减少, 气温逐渐降低。近 $14 \mathrm{a}$ 研究区整体呈现暖 湿化的态势, 降水量的变化幅度在-15.6 25.6 mm 之间, 变化的多年均值为 $7.9 \mathrm{~mm} / \mathrm{a}$, 气温在 -0.08 $0.06{ }^{\circ} \mathrm{C}$ 范围内变化, 多年均值为 $0.00035{ }^{\circ} \mathrm{C} / \mathrm{a}$ 。降水 减少的区域分布在北部遵义、铜仁、毕节、六盘水, 气温下降的区域分布于研究区中部大部分和西北 小部分地区。
(2) NDVI 与降水的偏相关系数范围为 $-0.81 \sim$ 0.87 ,均值为 0.17 。绝大部分地区 (约 $72 \%)$ 的区域显 示NDVI 与降水呈正相关, 主要分布在研究区东部; NDVI 与气温的偏相关系数在 $-0.71 \sim 0.75$ 之间, 均 值为 -0.01 。具有正相关关系的区域占 $46.7 \%$, 分布 在区域的研究区西北和东南缘, NDVI 与气温负相 关的区域主要在中部(河池和黔西南自治州)。

(3) 气候因子和人类活动共同影响黔桂喀斯特 山区的植被 NDVI变化, 2002-2015 年,研究区 NDVI 残差和 NDVI 残差趋势的均值分别为 0.03 和 $0.0007 / \mathrm{a}$, 表明近十几年来人类活动的正效应一直 在显现, 且有上升趋势。此外,这 $14 \mathrm{a}$ 内气候变化 对黔桂喀斯特山区植被年NDVI变化的影响远高于 人类活动(其平均贡献率达 $95 \%$ )。城市化的过程导 致建设用地增加, 大量耕地和林地被占用, 人类活 动对植被变化的负效应在毕节、安顺、贵阳以及河 池、柳州、百色附近较为明显。同时,在六盘水、黔 西南自治州、遵义和来宾,一系列生态还林等工程 也体现出人类活动对植被变化的正面影响。

\section{参考文献(References)}

杜加强, 贾尔恒·阿哈提, 赵晨曦, 等. 2016. 三江源区近 30 年 植被生长动态变化特征分析 [J]. 草业学报, 25(1):1-12. [Du J Q, Ahati J, Zhao C X, et al. 2016. Analysis of vegetation dynamics using GIMMS NDVI3g in the Three-Rivers Headwater region from 1982 to 2012. Acta Prataculturae Sinica, 25(1): 1-12. ]

郭敏杰. 2014. 基于 NDVI 的黄土高原地区植被覆盖度对气 候变化响应及定量分析 [D]. 北京: 中国科学院大学. [Guo M J. 2014. Responses of vegetation coverage to climate change on the Loess Plateau based on AVHRR/NDVI and its quantitative analysis. Beijing, China: University of Chinese Academy of Sciences. ]

侯美亭, 赵海燕, 王筝, 等. 2013. 基于卫星遥感的植被 NDVI 对气候变化响应的研究进展 [J]. 气候与环境研究, 18 (3): 353-364. [Hou M T, Zhao H Y, Wang Z, et al. 2013. Vegetation responses to climate change by using the satellite-derived normalized difference vegetation index: A review. Climatic and Environmental Research, 18(3): 353-364. ] 李昊, 蔡运龙, 陈睿山, 等. 2011. 基于植被遥感的西南喀斯 特退耕还林工程效果评价: 以贵州省毕节地区为例 [J]. 生态学报, 31(12): 3255-3264. [Li H, Cai Y L, Chen R S, et al. 2011. Effect assessment of the Project of Grain for Green in the karst region in Southwestern China: A case study of Bijie prefecture. Acta Ecologica Sinica, 31(12): 3255-3264. ] 李辉霞, 刘国华, 傅伯杰. 2011. 基于 NDVI 的三江源地区植 
被生长对气候变化和人类活动的响应研究 [J]. 生态学 报, 31(19): 5495-5504. [Li H X, Liu G H, Fu B J. 2011. Response of vegetation to climate change and human activity based on NDVI in the Three-River Headwaters region. Acta Ecologica Sinica, 31(19): 5495-5504. ]

刘梁美子, 占车生, 胡实, 等. 2018. 黔桂喀斯特山区植被变 化及其地形效应分析 [J]. 地理研究, 37(12): 2433-2446.

[Liu L M Z, Zhan C S, Hu S, et al. 2018. Analysis of the vegetation changes and its topographic effects in the karst mountainous area of Guizhou and Guangxi. Geographical Research, 37(12): 2433-2446. ]

刘志红, Li Lingtao, McVicar R, 等. 2008. 专用气候数据空间 插值软件 ANUSPLIN 及其应用 [J]. 气象, 34(2): 92-100.

[Liu Z H, Li L T, McVicar R, et al. 2008. Introduction of the professional interpolation software for meteorology data: ANUSPLINN. Meteorological Monthly, 34(2): 92-100. ] 蒙吉军, 王钧. 2007.20 世纪 80 年代以来西南喀斯特地区植 被变化对气候变化的响应 [J]. 地理研究, 26(5): 857-865.

[Meng J J, Wang J. 2007. The response of vegetation dynamics to climate change in the southwestern karst region of China since the early 1980s. Geographical Research, 26 (5): 857-865. ]

马明国, 王建, 王雪梅. 2006. 基于遥感的植被年际变化及其 与气候关系研究进展 [J]. 遥感学报, 10(3): 421-431. [Ma M G, Wang J, Wang X M. 2006. Advance in the inter-annual variability of vegetation and its relation to climate based on remote sensing. Journal of Remote Sensing, 10(3): 421-431. ]

孙建国, 王涛, 颜长珍. 2012. 气候变化和人类活动在榆林市 荒漠化过程中的相对作用 [J]. 中国沙漠, 32(3): 625-630. [Sun J G, Wang T, Yan C Z. 2012. The relative roles of climate change and human activities in desertification process: A case study in Yulin, Shaanxi Province, China. Journal of Desert Research, 32(3): 625-630. ]

孙艳玲, 延晓冬, 谢德体. 2007. 基于因子分析方法的中国植 被 NDVI 与气候关系研究 [J]. 山地学报, 25(1): 54-63. [Sun Y L, Yan X D, Xie D T. 2007. Study on the relationship between vegetation and climate in China using factor analysis. Journal of Mountain Science, 25(1): 54-63. ]

谭剑波, 李爱农, 雷光斌. 2016. 青藏高原东南缘气象要素 Anusplin 和 Cokriging 空间插值对比分析 [J]. 高原气象, 35(4): 875-886. [Tan J B, Li A N, Lei G B. 2016. Contrast on Anusplin and Cokriging meteorological spatial interpolation in southeastern margin of Qinghai-Xizang Plateau. Plateau Meteorology, 35(4): 875-886. ]

童晓伟, 王克林, 岳跃民, 等. 2014. 桂西北喀斯特区域植被 变化趋势及其对气候和地形的响应 [J]. 生态学报, 34 (12): 3425-3434. [Tong X W, Wang K L, Yue Y M, et al. 2014. Trends in vegetation and their responses to climate and topography in northwest Guangxi. Acta Ecologica Sini- ca, 34(12): 3425-3434. ]

王彦颖. 2016. 中国东北植被时空动态变化及其对气候响应 研究 [D]. 长春: 东北师范大学. [Wang Y Y. 2016. Study on temporal and spatial dynamic change of vegetation and its response to climate in Northeast China. Changchun, China: Northeast Normal University. ]

杨雪梅, 杨太保, 刘海猛, 等. 2016. 气候变暖背景下近 30a 北 半球植被变化研究综述 [J]. 干旱区研究, 33(2): 379-391. [Yang X M, Yang T B, Liu H M, et al. 2016. Vegetation variation in the North Hemisphere under climate warming in the last 30 years. Arid Zone Research, 33(2): 379-391. ]

姚永慧. 2005. 贵州喀斯特景观格局研究 [D]. 北京: 中国科 学院研究生院. [Yao Y H. 2005. Analysis of karst landscape pattern in Guizhou Province. Beijing, China: Graduate University of the Chinese Academy of Sciences. ]

于飞, 郑小波, 谷晓平, 等. 2008. 复杂山地环境下气候要素空 间插值精度比较研究 [J]. 贵州气象, 32(3): 3-6. [Yu F, Zheng X B, Gu X P, et al. 2008. Comparative study on spatial interpolation of climate elements precision in complex mountainous environment. Journal of Guizhou Meteorology, 32(3): 3-6. ]

张雪梅, 王克林, 岳跃民, 等. 2017. 生态工程背景下西南喀 斯特植被变化主导因素及其空间非平稳性 [J]. 生态学 报, 37(12): 4008-4018. [Zhang X M, Wang K L, Yue Y M, et al. 2017. Factors impacting on vegetation dynamics and spatial non- stationary relationships in karst regions of Southwest China. Acta Ecologica Sinica, 37(12): 4008-4018. ]

Archer E R M. 2004. Beyond the "climate versus grazing" impasse: Using remote sensing to investigate the effects of grazing system choice on vegetation cover in the eastern Karoo [J]. Journal of Arid Environments, 57: 381-408.

Evans J, Geerken R. 2004. Discrimination between climate and human induced dryland degradation [J]. Journal of Arid Environments, 57(4): 535-554.

Herrmann S M, Anyamba A, Tucker C J. 2017. Recent trends in vegetation dynamics in the African Sahel and their relationship to climate [J]. Global Environmental Change, 15(4): 394-404.

Hou W J, Gao J B, Wu S H, et al. 2015. Interannual variations in growing-season NDVI and its correlation with climate variables in the southwestern karst region of China [J]. Remote Sensing, 7(9): 11105-11124.

Hutchinson M F, Xu T B. 2013. Anusplin version 4.4 user guide [M/OL]. 2013-08-23[2018-11-13]. http://fennerschool anu.edu.au/files/anusplin44.pdf.

Ichii K, Kawabata A, Yamaguchi Y. 2002. Global correlation analysis for NDVI and climatic variables and NDVI trends: 1982- 1990 [J]. International Journal of Remote Sensing, 23(18): 3873-3878.

IPCC. 2013. Climate change 2013: The physical science basis, 
contribution of working group I to the fifth assessment report of the intergovernmental panel on climate change [M]. Cambridge, United Kingdom and New York, USA: Cambridge University Press.

Liu R, Xiao L L, Liu Z, et al. 2018. Quantifying the relative impacts of climate and human activities on vegetation changes at the regional scale $[\mathrm{J}]$. Ecological Indicators, 93: 91-99.

Liu Y X, Wang Y L, Du Y Y, et al. 2016. The application of polynomial analyses to detect global vegetation dynamics during 1982- 2012 [J]. International Journal of Remote Sensing, 37(7): 1568-1584.

Philippon N, Mougin E, Jarlan L, et al. 2005. Analysis of the linkages between rainfall and land surface conditions in the West African monsoon through CMAP, ERS- WSC, and NOAA-AVHRR data [J]. Journal of Geophysical Research Atmospheres, 110(D24): 1064-1067.

Tian Y C, Bai X Y, Wang S J, et al. 2017. Spatial-temporal changes of vegetation cover in Guizhou Province, Southern China [J]. Chinese Geographical Science, 27(1): 25-38.

Tong X W, Wang K L, Yue Y M, et al. 2017. Quantifying the effectiveness of ecological restoration projects on longterm vegetation dynamics in the karst regions of Southwest China [J]. International Journal of Applied Earth Observation and Geoinformation, 54: 105-113.

Wang J, Wang K L, Zhang M Y, et al. 2015. Impacts of climate change and human activities on vegetation cover in hilly Southern China [J]. Ecological Engineering, 81: 451-461.

Yin G, Hu Z Y, Chen X, et al. 2016. Vegetation dynamics and its response to climate change in Central Asia [J]. Journal of Arid Land, 8(3): 375-388.

Zhang Y, Zhang C B, Wang Z Q, et al. 2016. Vegetation dynamics and its driving forces from climate change and human activities in the Three- River Source region, China from 1982 to 2012 [J]. Science of the Total Environment, 563-564: 210-220.

\title{
Impact factors of annual NDVI change in karst mountain areas of Guizhou and Guangxi Provinces
}

\author{
LIU Liangmeizi ${ }^{1,2}$, ZHAN Chesheng $^{1 *}$, HU Shi ${ }^{1}$, ZHANG Qi ${ }^{1,2}$ \\ (1. Key Laboratory of Water Cycle and Related Land Surface Processes, Institute of Geographic Sciences and \\ Natural Resources Research, CAS, Beijing 100101, China; \\ 2. University of Chinese Academy of Sciences, Beijing 100049, China)
}

\begin{abstract}
The karst mountain areas are typical ecologically fragile regions in China. The vegetation is highly prone to degradation and is difficult to recover after that. In this study, we explored the change trend of climatic factors and distinguished the impact factors of annual NDVI change in karst mountain areas, by using stepwise regression, correlation analysis, and residual analysis. From 2002 to 2015, a warm and humid trend was found in the study area, but not significant at the $P=95 \%$ level. The average annual changes of precipitation and temperature are in the range of $-15.6-25.6 \mathrm{~mm} / \mathrm{a}$ and $-0.08-0.06{ }^{\circ} \mathrm{C} / \mathrm{a}$, with an increasing rate of $7.9 \mathrm{~mm} / \mathrm{a}$ and $0.00035^{\circ} \mathrm{C} / \mathrm{a}$ respectively at the regional scale. During the study period, climate variability was the dominating factor of NDVI changes, which accounted for $95 \%$ of the annual variations, and the impact of precipitation on NDVI was slightly greater than that of temperature. The residual analysis of NDVI showed that the mean values of NDVI residual and its trend were 0.03 and $0.0007 / \mathrm{a}$ in the last 14 years, indicating that the positive effects of human activities were present. Human activities such as urbanization caused a large amount of cultivated land and forest to be occupied by construction land, thus had obvious negative effects on NDVI changes in Bijie, Anshun, Guiyang, Hechi, Liuzhou, and Baise. However, due to the implementation of ecological rehabilitation and reforestation projects, human activities had positive effects on NDVI changes in Liupanshui, Qianxinan, Zunyi, and Laibin.
\end{abstract}

Keywords: vegetation change; climatic factors; human activities; karst mountain areas 